\title{
Impact of High-Pressure Homogenization on the Extractability and Stability of Phytochemicals
}

\author{
Shireena Xhiang Mun Yong ${ }^{1}$, Cher Pin Song ${ }^{2}$ and Wee Sim Choo ${ }^{1 *}$ \\ ${ }^{1}$ School of Science, Monash University Malaysia, Bandar Sunway, Malaysia, ${ }^{2}$ School of Engineering, Monash University \\ Malaysia, Bandar Sunway, Malaysia
}

OPEN ACCESS

Edited by:

Lourdes Maria Correa Cabral, Brazilian Agricultural Research Corporation (EMBRAPA), Brazil

Reviewed by:

Pedro Elez-Martinez,

Universitat de Lleida, Spain

Sergiy Smetana,

German Institute of Food

Technologies, Germany

Lourdes Masson,

State University of Rio de Janeiro, Brazil

*Correspondence:

Wee Sim Choo

choo.wee.sim@monash.edu

Specialty section:

This article was submitted to Sustainable Food Processing,

a section of the journal

Frontiers in Sustainable Food Systems

Received: 10 August 2020 Accepted: 10 December 2020 Published: 14 January 2021

Citation:

Yong SXM, Song CP and Choo WS (2021) Impact of High-Pressure Homogenization on the Extractability and Stability of Phytochemicals.

Front. Sustain. Food Syst. 4:593259. doi: 10.3389/fsufs.2020.593259
High-pressure homogenization $(\mathrm{HPH})$ and high-pressure processing (HPP) are emerging technologies for the food industry. Both technologies employ high pressure to preserve foods. However, the principal mechanism of HPH is based on shear stress distribution in a material instead of a decrease in volume due to an increase in pressure as occurring in HPP. HPH can be used in extraction or preservation of bioactive compounds and phytochemicals. This review first describes the mechanism of HPH processing. Next, this review discusses the impact of HPH on extractability and stability of phytochemicals such as carotenoids, vitamin C, polyphenols, and anthocyanins in various food matrices. In general, the use of $\mathrm{HPH}$ slightly improved or maintained the extractability of the phytochemicals. Similarly, HPH slightly reduced or maintained the stability of the phytochemicals but this is dependent on the food matrix and type of phytochemical. $\mathrm{HPH}$ has a great potential to be used to improve the extractability and maintaining the stability of these phytochemicals or to be used together with milder thermal processing. Besides understanding the impact of HPH on the extractability and stability of phytochemicals, the impact of HPH on the nutritional quality of the food matrices needs to be thoroughly evaluated.

\section{Keywords: anthocyanin, ascorbic acid, carotenoid, carotene, extraction, lycopene, phenolic acid, vitamin C}

\section{INTRODUCTION}

Phyto is a Greek word that means "plant." Hence, phytochemicals are chemicals derived from plants. They are secondary metabolites of plants that provide certain color, flavor, or for protection against pests and pathogens (Puri et al., 2012). Phytochemicals are small molecules in plant that constitutes about $10 \%$ or less of the plant matrix. They can be recovered from flowers, fruits, vegetables and herb using various extraction techniques (Harjo et al., 2004). Phenolic compounds belong to a large class of compounds with great diversity in their structures. Examples are simple phenolic acids that contain one hydroxyl group attached to an aromatic ring such as vanillin and caffeic acid. Besides simple phenols, there are polyphenols such as flavonoids and stilbenes in which the molecule bear a minimum of two phenolic rings. Example of these polyphenols include anthocyanin, proanthocyanins, and gallotannins (Cheynier, 2012). Carotenoid is a natural, lipid-soluble pigment occurring in plants, algae, and certain fungi. Carotenoid is located in the chloroplast and chromoplast of plants or bounded to a macromolecule such as fiber or protein (Serment-Moreno et al., 2017). Carotenoid contributes to yellow, orange and red color. The base structure of carotenoid consists of a branched five-carbon unit which is called isoprenoid (Boon et al., 2010). 
Conventional extraction techniques for the recovery of phytochemicals can be carried out using solid-liquid extraction method. These include maceration, infusion, Soxhlet extraction, and steam distillation method (Brennan et al., 2013). Soxhlet extraction is conventionally used for recovery of phytochemicals from plants and is frequently used as the reference technique to evaluate other conventional and non-conventional extraction techniques (Wang and Weller, 2006). Conventional techniques usually employ the use of polar or non-polar organic solvents except for steam distillation and infusion technique that employ water as solvent (Haroen et al., 2013; Dhanani et al., 2017).

Extraction yield of conventional solvent extraction methods are usually high but the usage of solvents in these techniques limits the application of the extracted phytochemicals in foods as solvents may pose harmful effects when ingested (Selvamuthukumaran and Shi, 2017). This issue may be solved by using food grade solvents but there are other challenges as well. These include long duration of extraction, high cost to use high purity solvent, and the use of heat treatment which will result in degradation of thermo labile phytochemicals (Azmir et al., 2013). Therefore, alternative approaches involving nonthermal or solvent-free extraction methods are highly desirable for application of phytochemicals in the food industry. Pulsedelectric field, supercritical fluid extraction and high-pressure processing are examples of non-conventional techniques (Azmir et al., 2013).

High pressure processing (HPP) applies pressure uniformly and transmit the pressure to a sample using a pressure transmitting medium at ambient or sub-ambient temperature for several minutes, without inducing a shearing effect. Although many food products such as fruit and vegetable beverages are commercially being treated with HPP for pasteurization, this process is not a continuous process and therefore only allowing a relatively low processing volume. On the other hand, high-pressure homogenization $(\mathrm{HPH})$, also known as high-pressure valve homogenization or dynamic high-pressure homogenization, is an emerging continuous flow process technology that enables homogenization and pasteurization or in certain cases, sterilization of fluids in one single step (Levy et al., 2020). HPH can be used in the food industry to inactivate spoilage or pathogenic microorganisms, prepare emulsions, reduce particle size and improve the rheological properties of food products. Research on the use of $\mathrm{HPH}$ to extract or increase the functionality of bioactive compounds has been increasing since the year 2010. It was suggested that this trend is due to increasing interest in the food industry to improve nutritional and organoleptic quality of foods, besides concern for food waste valorization. HPH technology is a green technology as it does not require the use of polluting solvents, short processing times, low energy consumption and carbon dioxide emissions (Mesa et al., 2020). In this context, HPH technology has huge potential for applications in the food industry. One of the emerging applications is the use of $\mathrm{HPH}$ technology for extraction of phytochemicals. However, information on the application of HPH technology for extraction of phytochemicals has to be derived from individual studies conducted. Thus, the application of $\mathrm{HPH}$ technology
TABLE 1 | Summary of distinguishing high-pressure homogenization from high-pressure processing.

\begin{tabular}{|c|c|c|}
\hline Description & $\begin{array}{l}\text { High-pressure } \\
\text { homogenization (HPH) }\end{array}$ & $\begin{array}{l}\text { High-pressure } \\
\text { processing (HPP) }\end{array}$ \\
\hline Principle & $\begin{array}{l}\text { - Distribution of shear } \\
\text { stress across products } \\
\text { - Changes in the structure } \\
\text { of the product }\end{array}$ & $\begin{array}{l}\text { - Equal distribution of } \\
\text { pressure in all directions } \\
\text { in products (isostatic } \\
\text { principle and principle of } \\
\text { Le Chatelier) } \\
\text { - Non-porous food will } \\
\text { maintain their } \\
\text { original shape }\end{array}$ \\
\hline Pressure level & 100-350 MPa & $400-600 \mathrm{MPa}$ \\
\hline Temperature rise & $\begin{array}{l}15-18^{\circ} \mathrm{C} / 100 \mathrm{MPa} \\
\text { - Irreversible }\end{array}$ & $\begin{array}{l}\text { 3- } 8^{\circ} \mathrm{C} / 100 \mathrm{MPa} \\
\text { - Reversible } \\
\text { upon decompression }\end{array}$ \\
\hline State of product & Liquid & Liquid and solid \\
\hline Mode of operation & Continuous & Batch and semi-continuous \\
\hline $\begin{array}{l}\text { Number of industrial } \\
\text { applications }\end{array}$ & Few & Many \\
\hline
\end{tabular}

Adapted from Martinez-Monteagudo et al. (2017) and Augusto et al. (2018).

for extraction of phytochemicals such as carotenoids and polyphenols, and its impact on their extractability is organized and discussed in this review. Phytochemicals are key components in foods that provide benefits to human health. As the main focus of most studies is either on the impact of $\mathrm{HPH}$ technology on microbial inactivation, physical stability or stability of macromolecules, this review also discusses the impact of $\mathrm{HPH}$ on the stability of various phytochemicals. The mechanism of $\mathrm{HPH}$ is also discussed.

\section{MECHANISM OF HPH}

$\mathrm{HPH}$ is a homogenization technology that results in the alteration of the physical structures and microbial and enzyme inactivation of food products. Both HPH and HPP technology are able to achieve microbial and enzyme inactivation in food products. However, the application of HPP depends on the pressure whereas the application of HPH is dependent on the distribution of shear stress across a product (Augusto et al., 2018). The difference between HPH and HPP is summarized in Table 1. $\mathrm{HPH}$ functions at an elevated pressure of more than $100 \mathrm{MPa}$ and is not limited to a single configuration. Figure 1 shows a general representation of HPH. With its homogenization pumps, valve and accessories, many configurations can be allowed but due to the particularities of the equipment such as valve design, only fluidic products and not particulate products can be used in $\mathrm{HPH}$. Therefore, $\mathrm{HPH}$ process is considered as a continuous process (Augusto et al., 2018).

The main components of HPH consists of a homogenization valve and a high-pressure pump. A pressure of $34 \mathrm{MPa}$ was considered as high-pressure homogenization in the early days; but $300 \mathrm{MPa}$ or more can be achieved (Diels and Michiels, 2006). HPH was defined by Harte (2016) as homogenization processes whereby the pumps can reach at least $100 \mathrm{MPa}$ to 


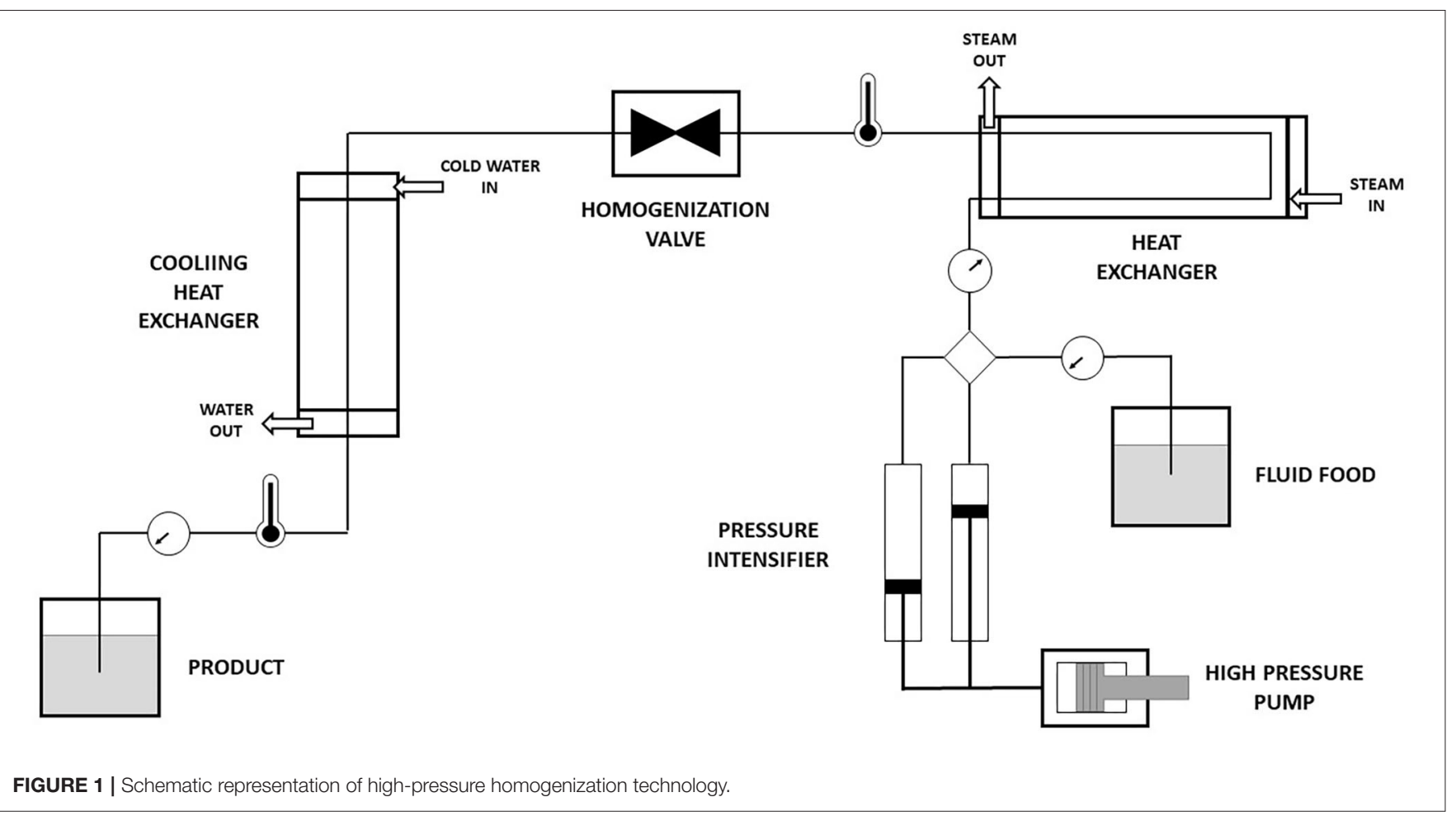

a liquid food. The $\mathrm{HPH}$ process carried out at upper pressure range of $200 \mathrm{MPa}$ or more is called an ultra-HPH (Marszałek et al., 2017). It should, however, be noted that the cut-off point between $\mathrm{HPH}$ and ultra-HPH can differ between authors. This is because HPH technologies are kept on evolving (Harte, 2016). Pressure is first intensified by the high-pressure pump that pressurizes a product that results in a fluid pressurization system. The high pressure generated can be up to $400 \mathrm{MPa}$ and acts as the driving force that results in the flow of the fluid through and beyond the homogenization valve (Georget et al., 2014; Marszałek et al., 2017; Augusto et al., 2018). Although the high pressure is the driving force of the homogenizer, the main work occurs at the homogenization valve. The homogenization valve consists of a small orifice (in order of micrometers) in between the valve and the valve seat (Figure 2). At the orifice of the valve, a fluid is subjected to shearing action as its motion is disrupted by this orifice (Sanguansri and Augustin, 2006). Different phenomena such as cavitation, turbulence, collision and impingement contributed to these shearing effects (MartinezMonteagudo et al., 2017). However, this review focuses on cavitation and turbulence.

\section{SHEARING EFFECTS OF HPH}

\section{Cavitation}

Due to abrupt reduction in pressure of the flowing liquid, cavitation occurs (Carlton, 2012) whereby cavities are formed followed by subsequent collapse within the liquid (Figure 3). This is a result of vaporized fluid condensation (MartinezMonteagudo et al., 2017). At the orifice of the valve, a continuous decrease in pressure is occurring due to fluid acceleration. When the fluid vapor pressure is reached, this allows vaporization which is the transition of liquid into vapor. When the fluid leaves the valve, an increase in the flow area for the fluid decreases its velocity. Thus, the pressure at the exit increases back to atmospheric pressure. Due to this, a great amount of energy is released that causes great shear stress because of the condensation of vaporized fluid (Augusto et al., 2018).

\section{Turbulence}

Turbulence is a phenomenon that occurs when the motion of a fluid is suddenly reduced by about 100-1,000 times around the valve. As the area for flowing fluid is abruptly reduced, velocity increases according to the law of mass conservation. With increasing velocity around the valve and high magnitude of velocity gradients, there is non-uniform fluid motion that gives rise to turbulent flow (Martinez-Monteagudo et al., 2017). Turbulent flow (Figure 3) enhances diffusivity of mixing as well as improving mass and heat transfer. Turbulent flow also causes generation of heat through dissipation of kinetic energy (Rosa, 2006). The dissipative nature of turbulence is important as sufficient energy is required to breakup particle and cause the formation of droplets (Martinez-Monteagudo et al., 2017).

\section{Heat of Homogenization}

Even though $\mathrm{HPH}$ is considered as a non-thermal process, increase in the temperature of food materials is unavoidable because of adiabatic heating. Turbulence as well as shearing and mixing effects of liquid during homogenization produces adiabatic heating. Therefore, it is important to control and 


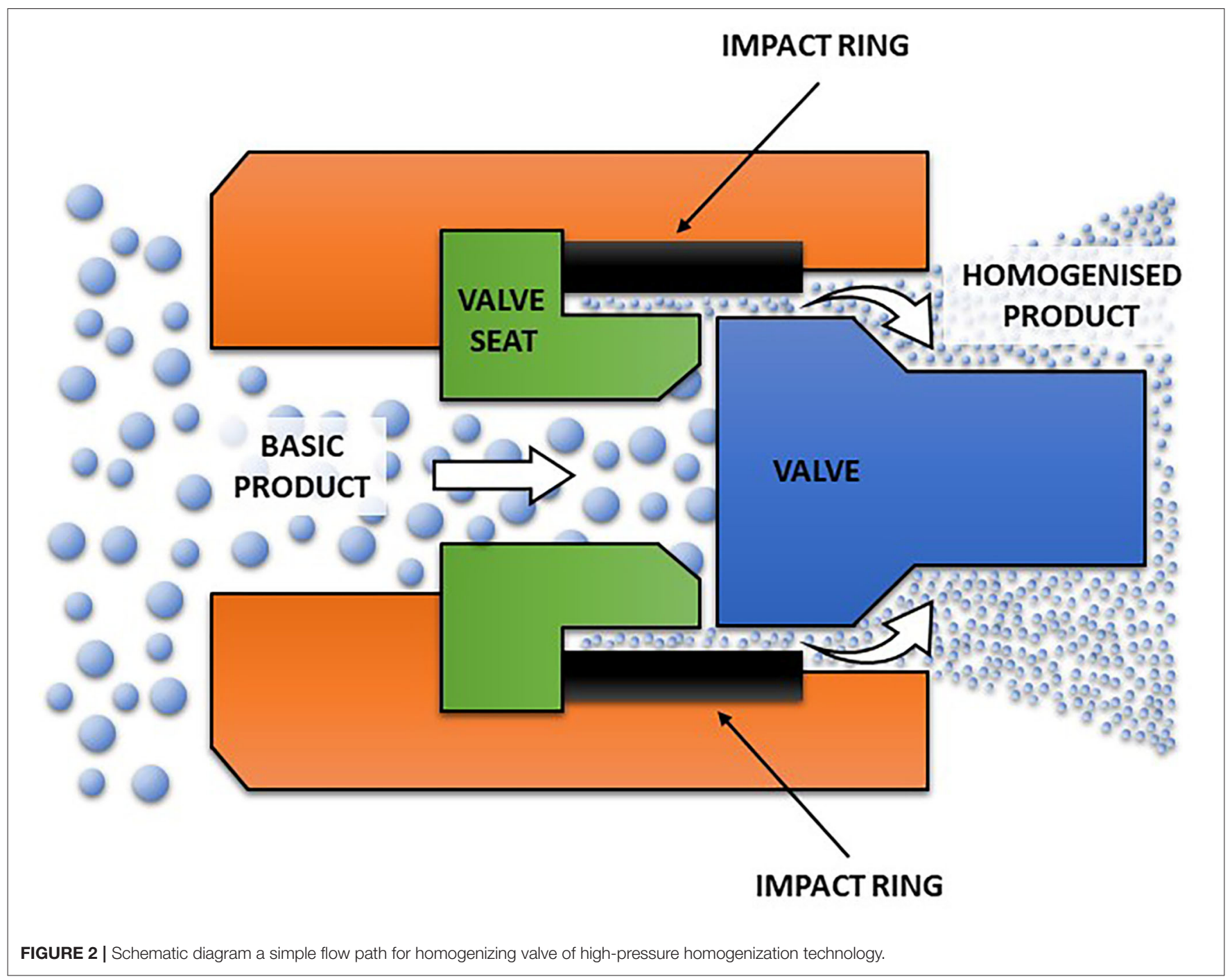

monitor the temperature of food materials after homogenization for prevention of over-heating and subsequent loss of heatsensitive molecules (Diels and Michiels, 2006; Dumay et al., 2013). Heat exchanger (Figure 1) following the homogenization valve (Augusto et al., 2018) is generally used to control the temperature of $\mathrm{HPH}$.

\section{IMPACT OF HPH ON EXTRACTABILITY OF PHYTOCHEMICALS}

Pre-treatment of phytochemicals with HPH before extraction is a relatively new approach. Hence, studies on the effect of $\mathrm{HPH}$ treatment on the extractability of phytochemicals is lesser studied in various food systems than studies on the stability of phytochemicals. Conventionally, phytochemicals are recovered from plant materials using solid-liquid extraction techniques but newer non-thermal and solvent-free approaches such as high-pressure extraction is being increasingly used for the extraction of phytochemicals (Cardoso et al., 2013;
Casquete et al., 2014). The hypothesis is that the use of $\mathrm{HPH}$ process may increase the extractability of any compound such as phytochemicals (Martinez-Monteagudo et al., 2017). Table 2 summarizes various conditions used in $\mathrm{HPH}$ and the effects of $\mathrm{HPH}$ on phytochemicals in several food matrices. The model, valve type and scalability of the HPH used are mentioned as reported by the authors of these studies. Current knowledge on $\mathrm{HPH}$ valves in terms of design, flow rate, operating pressure and scalability has been discussed in the review by MartinezMonteagudo et al. (2017).

\section{Phenolic Compounds}

There are limited studies on the impact of $\mathrm{HPH}$ on the extractability of phenolic compounds. Zhu et al. (2016) investigated the effect of $\mathrm{HPH}$ at a pressure of $158.58 \mathrm{MPa}$ and alkaline treatment for the extraction of phenolic acids from potato peels. With $\mathrm{HPH}$ treatment, an increase of $27.4 \%$ in extraction yield was obtained compared to that without $\mathrm{HPH}$ treatment. Combination of HPH and alkaline treatment in the extraction of phenolic acids further improved the extraction yield 


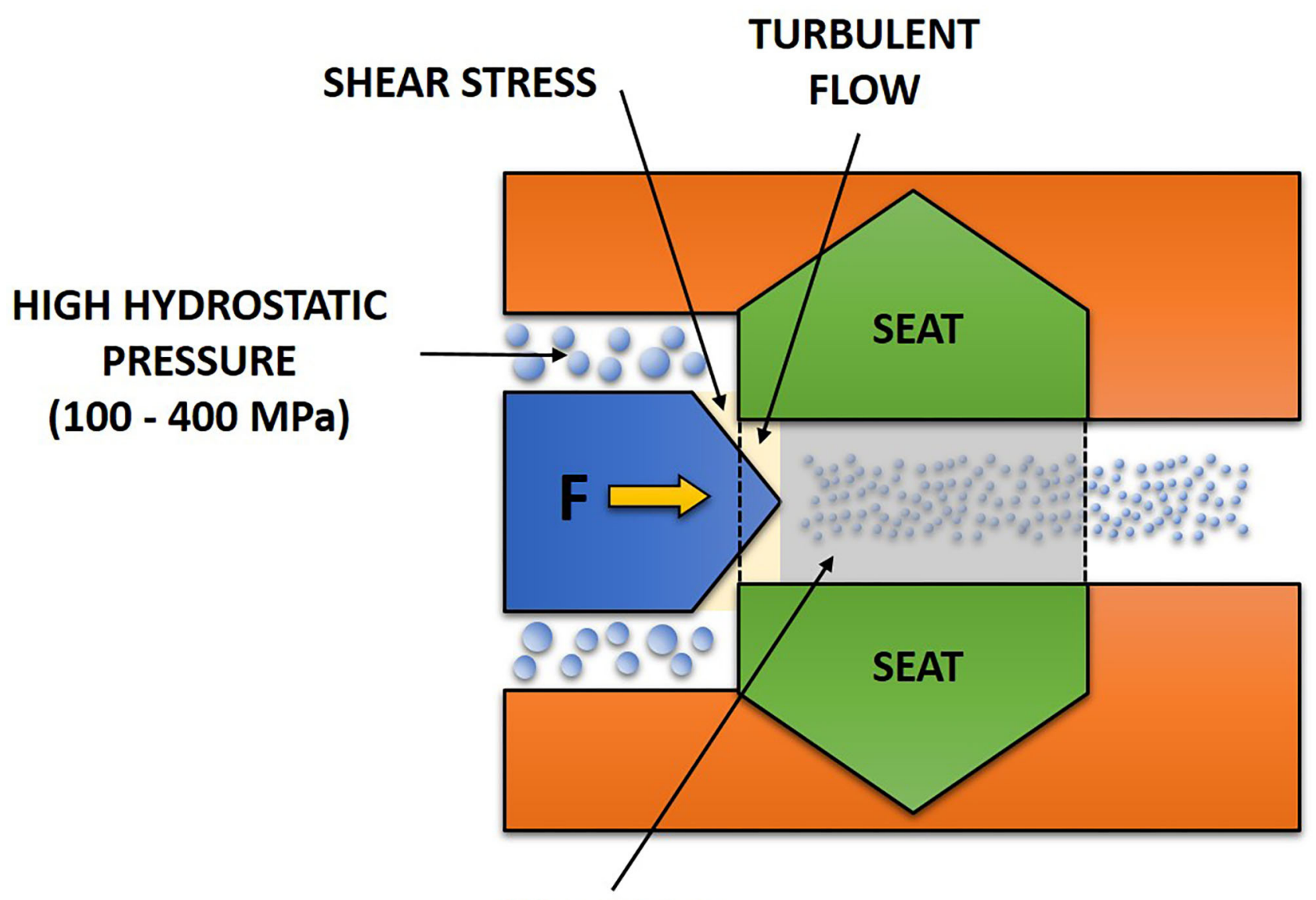

\section{CAVITATION}

FIGURE 3 | Occurrence of turbulent flow and cavitation in a fluid during high-pressure homogenization.

by $44.4 \%$. In these potato peels, the most abundant compounds are the free or bound phenolic acids (Samarin et al., 2012). $\mathrm{HPH}$ was suggested to cause structural changes to the cells by weakening the cell walls and releasing bound phenolic acids (Mattila and Kumpulainen, 2002).

$\mathrm{HPH}$ at $100 \mathrm{MPa}$ for $1-10$ passes with water as the process medium were used by Jurić et al. (2019) to extract valuable compounds from tomato peels. HPH treatment for 10 passes resulted in an increase in the extraction of polyphenols by $32.2 \%$ and was better than high-shear mixing at $5 \mathrm{~min}$ at 20,000 rpm. This was attributed to the release of intracellular compounds such as polyphenols is dependent mainly on the extent of cell disruption. These studies demonstrated positive effect of $\mathrm{HPH}$ on the extraction of phenolic acids from different food matrices, but they only utilized one pressure. Increasing the pressure of the $\mathrm{HPH}$ system or number of HPH cycles or passes is most likely going to increase the extractability of phenolic acids.

\section{Carotenoid}

The release of carotenoid by HPH processing is achieved through the mechanical disruption of plant cell walls. Plant cell walls are not able to withstand high shear stress occurring at the valve (Figure 3) of a high-pressure homogenizer (Colle et al., 2010a). Extraction of carotenoids from tomato peels into aqueous phase using $\mathrm{HPH}$ at $100 \mathrm{MPa}$ for $1-10$ passes was investigated by Jurić et al. (2019). Lycopene was found to be the main carotenoid in the pellet and supernatant of the aqueous phase after centrifugation. Interestingly, the pellet from aqueous phase treated by high-shear mixing at $5 \mathrm{~min}$ at 20,000 rpm contained higher amounts of lycopene than that by $5 \mathrm{HPH}$ passes whereas the supernatant from the aqueous phase treated by $5 \mathrm{HPH}$ passes contained higher amount of lycopene than that of highshear mixing. It was suggested that lycopene can be extracted from the tomato peel structure into the aqueous phase using $\mathrm{HPH}$. In addition, the yields of extraction of lycopene in this study was found to be comparable with other studies using solvent extraction assisted by cellulase and pectinase enzymes or ultrasound-assisted extraction but higher than those using pulsed electric field-assisted solvent extraction, supercritical carbon dioxide extraction, pressurized water extraction as well as conventional solvent extraction from dried tomato peels using various combinations of solvents (Jurić et al., 2019). Varying the 
TABLE 2 | The impact of high-pressure homogenization on phytochemicals.

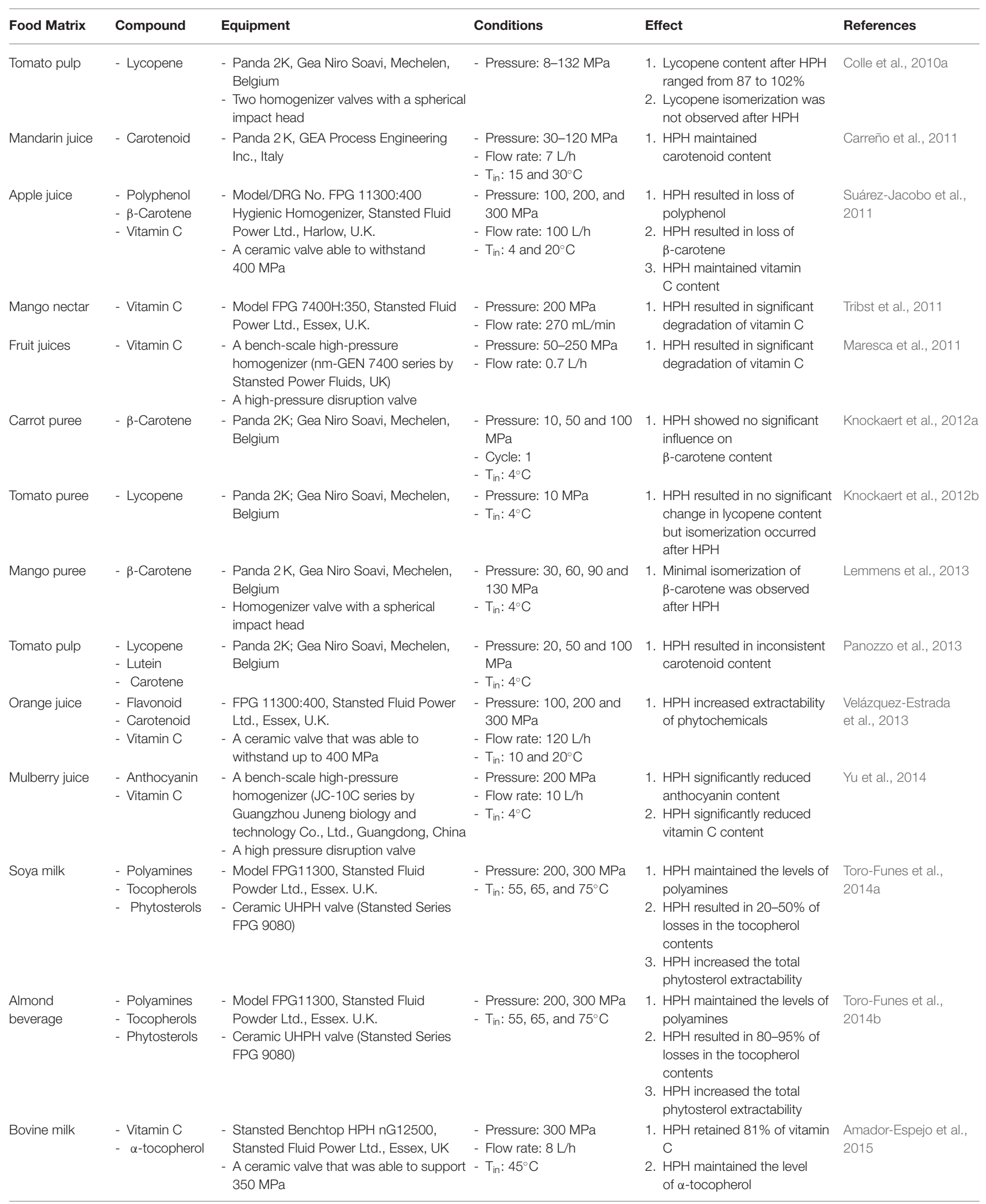


TABLE 2 | Continued

\begin{tabular}{|c|c|c|c|c|c|}
\hline Food Matrix & Compound & Equipment & Conditions & Effect & References \\
\hline Strawberry juice & - Polyphenol & $\begin{array}{l}\text { - Nano Disperser-NLM 100, } \\
\text { South Korea }\end{array}$ & $\begin{array}{l}\text { - Pressure: } 60 \text { and } 180 \\
\text { MPa } \\
\text { - Passes: } 2 \text { and } 5\end{array}$ & $\begin{array}{l}\text { 1. HPH maintained total } \\
\text { phenolic content at } 60 \mathrm{MPa} \\
\text { but increased the total } \\
\text { phenolic content at } 180 \mathrm{MPa}\end{array}$ & Karacam et al., 2015 \\
\hline Almond milk & $\begin{array}{l}\text { - Vitamins B1 } \\
\text { and B2 }\end{array}$ & $\begin{array}{l}\text { - MRI in-house HPH system } \\
\text { - Dunze Hochdrucktechnik GmbH, } \\
\text { Hamburg, Germany, Type 402-60-2, } \\
\text { nominal valve size DN, } 2.8 \mathrm{~mm}\end{array}$ & $\begin{array}{l}\text { - Pressure: } 350 \mathrm{MPa} \\
\text { - Flow rate: } 0.5 \mathrm{~mL} / \mathrm{s} \\
\text { - } \mathrm{T}_{\text {in }}: 85^{\circ} \mathrm{C}\end{array}$ & $\begin{array}{l}\text { 1. HPH maintained the levels of } \\
\text { vitamins } B_{1} \text { and } B_{2}\end{array}$ & Briviba et al., 2016 \\
\hline Potato peel & - Phenolic acid & $\begin{array}{l}\text { - Brand name was not provided } \\
\text { by authors }\end{array}$ & $\begin{array}{l}\text { - Pressure: } 158.8 \mathrm{MPa} \\
\text { - Cycles: } 2\end{array}$ & $\begin{array}{l}\text { 1. HPH improved the extraction } \\
\text { of phenolic acids }\end{array}$ & Zhu et al., 2016 \\
\hline $\begin{array}{l}\text { Apple juice } \\
\text { Grape juice } \\
\text { Orange juice }\end{array}$ & - Phenolic acid & $\begin{array}{l}\text { - Nano homogenize machine, ATS } \\
\text { Engineering Inc., Canada }\end{array}$ & Pressure: $250 \mathrm{MPa}$ & $\begin{array}{l}\text { 1. HPH decreased the total } \\
\text { phenolic content of apple } \\
\text { juice } \\
\text { 2. HPH increased the total } \\
\text { phenolic content of grape and } \\
\text { orange juices }\end{array}$ & He et al., 2016 \\
\hline Tomato juice & - Carotenoids & $\begin{array}{l}\text { - A pilot-scale HPH (FPG11300:350, } \\
\text { Stansted Fluid Power Ltd., Essex, UK) } \\
\text { - Two-stage valves }\end{array}$ & $\begin{array}{l}\text { - Pressure: } 246 \mathrm{MPa} \\
\text { - Flow rate: } 90 \mathrm{~L} / \mathrm{h} \\
\text { - } \mathrm{T}_{\text {in }}: 99^{\circ} \mathrm{C}\end{array}$ & $\begin{array}{l}\text { 1. HPH maintained } \beta \text {-carotene } \\
\text { and total lycopene content }\end{array}$ & Yan et al., 2017 \\
\hline Brocolli & - Vitamin C & - HOMOLAB, FBF, Italy & Pressure: $10-100 \mathrm{MPa}$ & $\begin{array}{l}\text { 1. } \mathrm{HPH} \text { increased the extraction } \\
\text { yield of vitamin } \mathrm{C} \text { by } 152.8 \% \\
\text { for floret and } 44.1 \% \text { for stalk }\end{array}$ & Yang et al., 2018 \\
\hline Tomato peels & $\begin{array}{l}\text { - Lycopene } \\
\text { - Polyphenols }\end{array}$ & $\begin{array}{l}\text { - An orifice valve assembly (orifice } \\
\text { diameter of } 150 \mu \mathrm{m})\end{array}$ & $\begin{array}{l}\text { - Pressure: } 100 \mathrm{MPa} \\
\text { - } \mathrm{T}_{\text {in }} \text { : Below } 24^{\circ} \mathrm{C} \\
\text { - Passes: } 10\end{array}$ & $\begin{array}{l}\text { 1. HPH enabled recovery of } \\
\text { Iycopene up to } 56.1 \% \text { of the } \\
\text { initial peel content } \\
\text { 2. HPH increased the extraction } \\
\text { of polyphenols by } 32.2 \%\end{array}$ & Jurić et al., 2019 \\
\hline Carrot juice & - Carotenoids & - JN02HC, Guangzhou Juneng, China & $\begin{array}{l}\text { - Pressure: } 20,60 \text {, and } 180 \\
\text { MPa } \\
\text { - } \mathrm{T}_{\text {in }}: 25,50 \text {, and } 70^{\circ} \mathrm{C} \\
\text { - Passes: } 1,2 \text {, and } 3\end{array}$ & $\begin{array}{l}\text { 1. } \mathrm{HPH} \text { increased total } \\
\text { carotenoid bioaccessibility }\end{array}$ & Liu et al., 2019c \\
\hline Carrot beverage & - Carotenoids & - JN-02HC, Guangzhou Juneng, China & $\begin{array}{l}\text { - Pressure: } 60,120, \text { and } \\
180 \mathrm{MPa} \\
\text { - } \mathrm{T}_{\text {in }}: 25 \text { and } 60^{\circ} \mathrm{C} \\
\text { - Passes: } 1 \text { and } 3\end{array}$ & $\begin{array}{l}\text { 1. HPH resulted in better total } \\
\text { carotenoid content } \\
\text { during storage }\end{array}$ & Liu et al., 2019b \\
\hline Carrot juice & - Carotenoids & - JN02HC, Guangzhou Juneng, China & $\begin{array}{l}\text { - Pressure: } 20,60,100 \text {, } \\
\text { 150, and } 180 \mathrm{MPa} \\
\text { - } \mathrm{T}_{\text {in }}: 25,50, \text { and } 70^{\circ} \mathrm{C} \\
\text { - Passes: } 1,2 \text {, and } 3\end{array}$ & $\begin{array}{l}\text { 1. HPH maintained total } \\
\text { carotenoid content }\end{array}$ & Liu et al., 2019ca \\
\hline $\begin{array}{l}\text { Strawberry } \\
\text { nectar }\end{array}$ & $\begin{array}{l}\text { - Anthocyanin } \\
\text { - Polyphenol }\end{array}$ & $\begin{array}{l}\text { - PFK FPG12800, Stansted Fluid } \\
\text { Power, U.K. }\end{array}$ & $\begin{array}{l}\text { - Pressure: } 50,100,150, \\
\text { and } 200 \mathrm{MPa} \\
\text { - Passes: } 1,3 \text {, and } 5 \\
\text { - } \mathrm{T}_{\text {in }}: 25^{\circ} \mathrm{C}\end{array}$ & $\begin{array}{l}\text { 1. HPH slightly affected } \\
\text { anthocyanin content } \\
\text { 2. HPH maintained total } \\
\text { phenolic content }\end{array}$ & $\begin{array}{l}\text { Moscovici Joubran } \\
\text { et al., } 2019\end{array}$ \\
\hline Kiwi juice & - Polyphenol & $\begin{array}{l}\text { - PANDA (GEA, Parma, Italy) } \\
\text { - A R-type valve }\end{array}$ & $\begin{array}{l}\text { - Pressure: } 200 \mathrm{MPa} \\
\text { - } \mathrm{T}_{\text {in }}: 4^{\circ} \mathrm{C} \\
\text { - Cycles: } 2 \text { and } 3\end{array}$ & $\begin{array}{l}\text { 1. HPH increased total } \\
\text { phenolic content }\end{array}$ & Patrignani et al., 2019 \\
\hline Rosehip nectar & - Carotenoid & $\begin{array}{l}\text { - Two-stage HPH (GEA Niro Soavi-Panda } \\
\text { Plus } 2000 \text { Homogenizer, Parma, Italy) }\end{array}$ & $\begin{array}{l}\text { - Pressure: 75, 100, and } \\
125 \mathrm{MPa} \\
\text { - Passes: 1, 2, and } 3\end{array}$ & $\begin{array}{l}\text { 1. HPH increased total } \\
\text { carotenoid content with } \\
\text { increasing passes }\end{array}$ & Saricaoglu et al., 2019 \\
\hline Lettuce waste & - Polyphenol & $\begin{array}{l}\text { - A continuous lab-scale high-pressure } \\
\text { homogenizer (Panda Plus 2000, GEA } \\
\text { Niro Soavi, Parma, Italy) } \\
\text { - Two PS type valves }\end{array}$ & $\begin{array}{l}\text { - Pressure: } 80 \text { and } 150 \\
\text { MPa } \\
\text { - Flow rate: } 10 \mathrm{~L} / \mathrm{h} \\
\text { - Cycles: } 1 \text { and } 10\end{array}$ & $\begin{array}{l}\text { 1. HPH partially maintained } \\
\text { phenol content }\end{array}$ & $\begin{array}{l}\text { Plazzotta and } \\
\text { Manzocco, } 2019\end{array}$ \\
\hline Peach juice & $\begin{array}{l}\text { - Ascorbic acid } \\
\text { - Polyphenol }\end{array}$ & $\begin{array}{l}\text { - Two-stage HPH, SPX Flow Technology, } \\
\text { soeborg, Denmark }\end{array}$ & $\begin{array}{l}\text { - Pressure: } \sim 55 \mathrm{MPa} \\
\text { - } \mathrm{T}_{\text {in }}: 45^{\circ} \mathrm{C}\end{array}$ & $\begin{array}{l}\text { 1. HPH decreased ascorbic acid } \\
\text { content } \\
\text { 2. HPH increased total } \\
\text { phenolic content }\end{array}$ & Yildiz, 2019 \\
\hline $\begin{array}{l}\text { Pomelo and kiwi } \\
\text { juices }\end{array}$ & - Polyphenol & - ATS Engineering Inc., Canada & Pressure: $250 \mathrm{MPa}$ & $\begin{array}{l}\text { 1. HPH increased total } \\
\text { phenolic content }\end{array}$ & Quan et al., 2020 \\
\hline $\begin{array}{l}\text { Mixed carrot, } \\
\text { apple, and }\end{array}$ & - Polyphenol & $\begin{array}{l}\text { - JN-02HC series, Guangzhou } \\
\text { Juneng, China }\end{array}$ & $\begin{array}{l}\text { - Pressure: } 140 \mathrm{MPa} \\
\text { - } \mathrm{T}_{\text {in }}: 25^{\circ} \mathrm{C}\end{array}$ & $\begin{array}{l}\text { 1. HPH increased total } \\
\text { phenolic content }\end{array}$ & Wellala et al., 2020 \\
\hline
\end{tabular}

peach juices 
pressure of the HPH system or number of HPH cycles or passes is most likely going to affect the extractability of carotenoids.

\section{IMPACT OF HIGH-PRESSURE HOMOGENIZATION ON THE STABILITY OF PHYTOCHEMICALS}

$\mathrm{HPH}$ process is conventionally utilized mainly for enzyme and microbial inactivation in the food industry (Welti-Chanes et al., 2009; Carreño et al., 2011). The decrease of microbial count in $\mathrm{HPH}$-treated food material is usually not accompanied by a loss in nutritional value (Hayes et al., 2005; Calligaris et al., 2012). As $\mathrm{HPH}$ is a non-thermal process, it is usually regarded that HPH would cause minimal impact on the stability of phytochemicals. The following sections discussed the impact of $\mathrm{HPH}$ on the stabilities of vitamin $\mathrm{C}$, phenolic compounds and carotenoid in several food matrices.

\section{Vitamin C}

The stability of L-ascorbic acid is influenced by the presence of light, oxygen and temperature (Volf et al., 2014). The retention of $\mathrm{L}$-ascorbic acid in mango nectar with combination of $\mathrm{HPH}$ at $200 \mathrm{MPa}$ and heat treatment $\left(61.5\right.$ and $\left.75.5^{\circ} \mathrm{C}\right)$ was investigated by Tribst et al. (2011). In addition, HPH treatments without combination with heat treatment at $200 \mathrm{MPa}$ and $300 \mathrm{MPa}$ were also investigated. The retention of $\mathrm{L}$-ascorbic acid in mango nectar was found to be low. HPH treatment resulted in $~ 50 \%$ losses of L-ascorbic acid. However, this is in contrast with the study of Pérez-Conesa et al. (2009), who reported that HPH at 10,15 and $20 \mathrm{MPa}$ did not reduce the L-ascorbic acid content in tomato. This was most likely due to the low pressure that was employed in the HPH treatment (Zhou et al., 2017). Besides, the presence of oxygen in the mango nectar and increase in temperature during $\mathrm{HPH}$ could result in degradation of Lascorbic acid (Tribst et al., 2011). Hence, deaeration to remove oxygen is recommended prior to $\mathrm{HPH}$ processing.

The effect $\mathrm{HPH}$ treatment from 50 to $250 \mathrm{MPa}$ on commercial orange, red orange, pineapple fruit juices and Annurca apple juice was investigated (Maresca et al., 2011). The vitamin C concentration of the HPH treated juice was reported to be similar to the fresh juices. It was suggested that the HPH treatment did not significantly cause the degradation of vitamin $\mathrm{C}$ in the juices (Maresca et al., 2011). The effect of $\mathrm{HPH}$ at 100, 200, and 300 $\mathrm{MPa}$ on $\mathrm{L}$-ascorbic acid content in orange juice in comparison to thermal pasteurization $\left(90^{\circ} \mathrm{C}\right.$ for $1 \mathrm{~min}$ ) was investigated by Velázquez-Estrada et al. (2013). There was a gradual decrease of L-ascorbic acid content (1.7, 4.6, and 10.7\%) at pressures of 100, 200, and $300 \mathrm{MPa}$, respectively. However, HPH-treated juices retained L-ascorbic acid better than pasteurized juice with a decrease of $20.1 \%$. This study is in accordance with another study using apple juice (Suárez-Jacobo et al., 2011). In contrast, the degradation of $\mathrm{L}$-ascorbic acid due to a gradual increase in $\mathrm{HPH}$ pressure is not in accordance with the study by Welti-Chanes et al. (2009) in which the stability of L-ascorbic acid in orange juice remained stable after $\mathrm{HPH}$ treatment at 50-250 MPa. The degradation of L-ascorbic acid during storage is deduced to be more influenced by oxygen, temperature and light instead of the initial HPH treatment (Sharabi et al., 2018). The presence of trace metals in the processing equipment could also promote the degradation of L-ascorbic acid (Ball, 2006; Tribst et al., 2011).

The effect of $\mathrm{HPH}$ treatment at 75,100 , and $125 \mathrm{MPa}$ on the ascorbic acid content of rosehip nectar was investigated by Saricaoglu et al. (2019). HPH treatment was found to decrease the ascorbic acid content of rosehip nectar as compared to the control. There were no significant differences between the ascorbic acid content of rosehip nectar treated at 75 and 100 $\mathrm{MPa}$ but the lowest ascorbic acid content in rosehip nectar was obtained using $125 \mathrm{MPa}$ (Saricaoglu et al., 2019). HPH treatment at approximately $55 \mathrm{MPa}$ for $3 \mathrm{~min}$ with an inlet temperature of $45^{\circ} \mathrm{C}$ of peach juice was found to be better than heat treatment at $72^{\circ} \mathrm{C}$ for $15 \mathrm{~s}$ in retention of ascorbic acid and total phenolic contents. However, ultrasonic homogenization at a frequency of $20 \mathrm{kHz}$ was better than $\mathrm{HPH}$ treatment in retention of ascorbic acid and phenolic compounds of the peach juice (Yildiz, 2019). Overall, ascorbic acid is susceptible to degradation during HPH treatment.

\section{Phenolic Compounds}

The stability of phenolic compounds after isolation from their respective plant matrix is crucial as they are susceptible toward degradation in the presence of thermal stress or oxygen from the external environment (Karaaslan et al., 2013). The stability of anthocyanin in bilberry juice upon HPH and thermal treatment was investigated (Frank et al., 2012). Encapsulation of bilberry juice in monolayers of triglycerides was first carried out followed by thermal treatment, $\mathrm{HPH}$ at pressures from 30 to $150 \mathrm{MPa}$ or combination of both thermal and HPH treatment. The anthocyanin content in the bilberry juice after HPH treatment remained relatively similar to untreated juice but thermal treatment caused degradation of the anthocyanin content. This study shows that the stability of anthocyanin is maintained even after mechanical stress induced by HPH treatment (Patras et al., 2010; Marszałek et al., 2017).

The impact of HPH on the polyphenol content of apple juice was investigated (Suárez-Jacobo et al., 2011). Fresh apple juices were subjected to HPH treatment at pressures of 100 , 200 , and $300 \mathrm{MPa}$ or thermal treatment at $90^{\circ} \mathrm{C}$ for $4 \mathrm{~min}$. The total polyphenol content of apple juices decreased (10.6, 6.0, and $1.4 \%$ ) when subjected to $\mathrm{HPH}$ treatment under pressure of 100 , 200, and $300 \mathrm{MPa}$, respectively, as compared to pasteurized juices. This indicates that the polyphenols were more stable with increasing pressure. Nevertheless, polyphenols in apple juice are generally not stable due to the presence of polyphenol oxidase, an enzyme that can cause degradation of polyphenols (Buckow et al., 2009). It was suggested that polyphenol oxidase remained stable at low pressures lower than $200 \mathrm{MPa}$ and oxidized the polyphenols. However, the high pressure of $300 \mathrm{MPa}$ must have inactivate the enzyme (Schilling et al., 2008), hence, there was no significant impact of $\mathrm{HPH}$ on total polyphenol content of apple juice. On the contrary, $300 \mathrm{MPa}$ was reported in other studies to unable to inactivate PPO in apple juices (Saldo et al., 2009; Mckay et al., 2011). 
Velázquez-Estrada et al. (2013) investigated the effect of ultra $\mathrm{HPH}$ and thermal pasteurization on the properties of orange juice. Orange juice was heated at $90^{\circ} \mathrm{C}$ for $1 \mathrm{~min}$ for thermal pasteurization whereas for $\mathrm{HPH}$ processing, orange juice was pressurized to 100,200 , and $300 \mathrm{MPa}$. The polyphenol content decreased by $0.77 \%(100 \mathrm{MPa}), 1.54 \%$ (200 MPa), and $6.61 \%$ (300 MPa). Although polyphenol content was reduced because of $\mathrm{HPH}$ treatment, it was significantly lower than that of thermal pasteurization which showed a decrease of $19.0 \%$. This study showed that the degradation of polyphenols was minimized under non-thermal treatments (Oancea et al., 2018).

There was no effect of $\mathrm{HPH}$ treatment at $60 \mathrm{MPa}$ on the total phenolic content of strawberry juice. However, HPH treatment at $100 \mathrm{MPa}$ resulted in an increase on the total phenolic content of strawberry juice. Increasing $\mathrm{HPH}$ passes from 2 to 5 also resulted in in an increase on the total phenolic content of strawberry juice (Karacam et al., 2015). HPH treatment at 250 $\mathrm{MPa}$ for $10 \mathrm{~min}$ decreased the total phenolic content of apple juice but increased the total phenolic contents in grape and orange juices. It was suggested that $\mathrm{HPH}$ treatment ruptured the cellular structure of grape and orange fruits, favoring the release of bound phenolic substances from these fruit cells and hence enhancing their phenolic content but for apple juice, size reduction of plant tissues might have led to the interaction of cytoplasmic polyphenol oxidase and phenolic compounds in the vacuoles and result in oxidative degradation of the phenolic compounds (He et al., 2016).

The effect of $\mathrm{HPH}$ processing (200 $\mathrm{MPa}$ and thermal pasteurization $\left(95^{\circ} \mathrm{C}\right.$ for $\left.1 \mathrm{~min}\right)$ on the polyphenol content of mulberry juice was investigated by Yu et al. (2014). HPH caused a reduction in the anthocyanin content, cyanidin 3-rutinoside and cyanidin-3-glucoside by 33.2 and $38.8 \%$, respectively, in mulberry juice. This was due to the presence of PPO. This study is in accordance with the study on apple juice in which a pressure of $200 \mathrm{MPa}$ was found to be insufficient to inactivate PPO (SuárezJacobo et al., 2011). HPH processing may promote the oxidation of PPO through the exposure of active sites as a result of a change in its conformation (Liu et al., 2009; Bot et al., 2018). However, the pressure used in $\mathrm{HPH}$ processing has to be high enough $(\geq 300 \mathrm{MPa})$ to result in inactivation of PPO.

The inactivation of oxidative enzymes by the use of blanching prior to HPH produces a color-stable juice but blanching can cause significant reduction in phenolic content. This is because the applied heat and leaching effect in the water used in blanching. Ground lettuce waste was firstly homogenized at $40 \mathrm{MPa}$ before proceeding to $\mathrm{HPH}$ treatments at 80 and 150 $\mathrm{MPa}$. The combination of $\mathrm{HPH}$ with a blanching pre-treatment resulted in a homogeneous lettuce juice with partially maintained polyphenolic content (Plazzotta and Manzocco, 2019). Rosehip nectar treated at $125 \mathrm{MPa}$ resulted in higher total phenolic content than that treated at $75 \mathrm{MPa}$. This was attributed to the decreasing particle size and releasing of materials from the cells (Saricaoglu et al., 2019). The total phenolic content of kiwifruit juices with ultra HPH treatment at $200 \mathrm{MPa}$ for 3 cycles significantly increased in comparison to the control from 35 to 42 $\mathrm{mg} / 100 \mathrm{~mL}$ of juice. These results indicate that an increase in the availability of phenolic compounds (Patrignani et al., 2019).
The effect of HPH treatment up to $200 \mathrm{MPa}$ on the total phenolic content of strawberry nectar was investigated by Moscovici Joubran et al. (2019). The anthocyanin content was only slightly affected by the HPH pressure levels. The total phenolic content was not affected by $\mathrm{HPH}$ pressure levels but significantly increased up to $30 \%$ following number of $\mathrm{HPH}$ passes. This was attributed to more extraction of polyphenols from the achenes and pulp of strawberry (Moscovici Joubran et al., 2019). $\mathrm{HPH}$ treatment at $140 \mathrm{MPa}, 25^{\circ} \mathrm{C}$ was found to enhance the total phenolic content of carrot, apple and peach mixed juices. This was attributed to the release of more polyphenols from the vacuoles of different fruits as a result of intensive cell disruption (Wellala et al., 2020). There were no significant differences between $\mathrm{HPH}$-treated (250 MPa for $10 \mathrm{~min})$ and thermally treated $\left(80^{\circ} \mathrm{C}\right.$ for $30 \mathrm{~min}$ and $90^{\circ} \mathrm{C}$ for $30 \mathrm{~s})$ kiwi and pomelo juice in terms of total phenolic content. Both treatments showed an increase of $10.6-17.5 \%$ in total phenolic acids. This was attributed to both treatments were able to damage plant cell walls that assisted in the release of phenolic compounds (Quan et al., 2020). Overall, HPH processing affects the stability of phenolic compounds in juices but depending on the pressure that was applied and number of $\mathrm{HPH}$ passes.

\section{Carotenoid}

Carotenoid content in fruits is depending on their stage of developmental and environmental growth conditions. Lutein is the most representative carotenoid at the green stage of fruit, which reflects the characteristic of chloroplastic tissues, followed by $\beta$-carotene, violaxanthin and neoxanthin (Choo, 2019). Carotenoids contain a conjugated system of double bonds that are susceptible to oxidation and isomerization (Boon et al., 2010). These chemical reactions occur frequently during thermal processing due to high heat and exposure to oxygen. $\mathrm{HPH}$ processing may maintain the stability of carotenoid as $\mathrm{HPH}$ is non-thermal technology.

The effect of $\mathrm{HPH}$ has been investigated in tomatoes, carrots and mango fruits. It was found that the effect of $\mathrm{HPH}$ process on tomatoes varied according to the homogenization pressure $(8.4-132.7 \mathrm{MPa})$. The total lycopene content ranged between 87 and $102 \%$ following these different pressure treatment (Colle et al., 2010a). This variation in the lycopene content may be due to the variability between the tomatoes as well as ripeness of the tomatoes (Martínez-Valverde et al., 2002). Knockaert et al. (2012a) compared the equivalent thermal and high pressure sterilization processes of $\mathrm{HPH}$-treated tomato puree with olive oil. No significant differences were found between the thermal and high pressure sterilization processes. Panozzo et al. (2013) investigated the effect of $\mathrm{HPH}$ at pressures of 20, 50, and $100 \mathrm{MPa}$ on carotenoid content in red, orange and yellow tomato cultivars. The type of carotenoid in each tomato differed according to the types of tomatoes. Lycopene is the predominant carotenoid in red tomatoes whereas lutein was the predominant carotenoid in yellow tomatoes. Carotene was found predominantly in orange tomatoes (Rizk et al., 2014; Chaudhary et al., 2018). This variability in the type of predominant carotenoid was also due to the ripeness of the tomatoes (Zeng et al., 2015). Lutein in the globular chromoplast 
was found to be more resistant to rupture than the lycopeneresiding crystalloid ones. The crystalline state of lycopene is more fragile and can be easily ruptured by mechanical stress (Schweiggert et al., 2012). Panozzo et al. (2013) found that tomato cells were completely distrupted with $\mathrm{HPH}$ treatment at $20 \mathrm{MPa}$ which ease the release of cellular content including lycopene, lutein and carotene. The increase in homogenization pressure further disrupted the cell material with only fragments of cells were observed for $\mathrm{HPH}$ treatment at $100 \mathrm{MPa}$ (Panozzo et al., 2013).

The effect $\mathrm{HPH}$ treatment on the isomerization and degradation of lycopene in tomato puree was investigated by Knockaert et al. (2012b). The lycopene content of HPH treated tomato puree was similar to the untreated puree. It was suggested that $\mathrm{HPH}$ at $10 \mathrm{MPa}$ was insufficient to result in the disruption of the cell walls of tomato puree (Knockaert et al., 2012b; Kubo et al., 2013; Zhou et al., 2017). A pressure $>50 \mathrm{MPa}$ was recommended. In addition, the lycopene in $\mathrm{HPH}$ treated tomato puree remained as the stable translycopene at $85.4 \%$ and cis-lycopene was at $14.6 \%$. There was no formation of cis-lycopene in untreated tomato puree. In tomato pulp, intense thermal pasteurization caused elevation of cis-lycopene from 14.6 to $26.8 \%$ (Colle et al., 2010b). Furthermore, 13-cis-lycopene was the predominant degradation product of lycopene (Khoo et al., 2011; Lemmens et al., 2013).

The stability of carotene in mango puree upon $\mathrm{HPH}$ and thermal treatment $\left(80-150^{\circ} \mathrm{C}\right.$ for $\left.20 \mathrm{~min}\right)$ was investigated by Shi et al. (1999). At 30, 60, 90, and $130 \mathrm{MPa}$, the ratio of $\beta$-carotene/total $\beta$-carotene was found to be $0.65,0.63,0.62$, and 0.55 , respectively. Isomerization of the stable trans- $\beta$-carotene was minimal as well. Isomerization of trans- $\beta$-carotene into cis- $\beta$ carotene would reduce its bioactivity and increase the susceptibility toward oxidation (Ball, 2006). The impact of $\mathrm{HPH}$ on the degradation and isomerization of carotenoids is depending on the pressure that was applied during $\mathrm{HPH}$ processing.

Carreño et al. (2011) studied the effect of $\mathrm{HPH}$ at pressure range of $0-120 \mathrm{MPa}$ on the total carotenoid content of mandarin juice as compared to thermal pasteurization $\left(90^{\circ} \mathrm{C}\right.$ for $\left.10 \mathrm{~s}\right)$ or HPP at $0-450 \mathrm{MPa}$. There was a decrease in total carotenoid content observed using HPH and HPP processing at 1.66 and $5.54 \%$, respectively. However, thermal processing was shown to increase the total carotenoid content by $6.80 \%$. Increasing pressure resulted in greater loss of carotenoid although all three treatments did not cause significant decrease of carotenoid content. The release of carotenoid from $\mathrm{HPH}$ processing is due to the mechanical disruption of plant cells within the chromoplast (Colle et al., 2010a; Palmero et al., 2016a,b).

Yan et al. (2017) investigated the impact of two high pressure techniques $\left(\mathrm{HPH}\right.$ treatment at $246 \mathrm{MPa}, 99^{\circ} \mathrm{C},<1 \mathrm{~s}$ and $\mathrm{HPP}$ at $600 \mathrm{MPa}, 46^{\circ} \mathrm{C}, 5 \mathrm{~min}$ ) and compared to that of thermal processing at $90^{\circ} \mathrm{C}, 90 \mathrm{~s}$ of tomato juice. Total lycopene content and isomerization in the tomato juice were not significantly affected by the HPH and HPP treatment. Similar results were obtained for $\beta$-carotene content. Thermal processing resulted in significant decrease in $\beta$-carotene content of tomato juice. It was proposed that these two pressurebased technologies have the potential for application in tomato juice processing with good carotenoid retention (Yan et al., 2017).

HPH treatment assisted by moderate inlet temperature (180 $\mathrm{MPa}, 1$ pass and $60^{\circ} \mathrm{C}$ ) showed better total carotenoid content of a carrot beverage stored at $4^{\circ} \mathrm{C}$ for 28 days than the combination of $\mathrm{HPH}$ and heat treatment at $90^{\circ} \mathrm{C}$ for $5 \mathrm{~min}$ (Liu et al., 2019b). Rosehip nectar treated at $125 \mathrm{MPa}$ resulted in higher total carotenoid content than that treated at $75 \mathrm{MPa}$. In addition, the total carotenoid content increased with increasing $\mathrm{HPH}$ passes from 1 to 3 passes. Lycopene is the main carotenoid in rosehip fruit (Saricaoglu et al., 2019). The effect of $\mathrm{HPH}$ treatment of carrot juice at 20,60,100,150, and $180 \mathrm{MPa}$ on the total carotenoid content of carrot juice was investigated by Liu et al. (2019a). The total carotenoid content was unaffected by the $\mathrm{HPH}$ treatment. $\mathrm{HPH}$ treatment at $180 \mathrm{MPa}$ with moderate inlet temperature of $60^{\circ} \mathrm{C}$ showed a better preservation of carotenoids in carrot beverage than $\mathrm{HPH}$ treatment combined with heat treatment at $90^{\circ} \mathrm{C}$ for $5 \mathrm{~min}$. During storage of the carrot beverage, the half-life, $\mathrm{t}_{1 / 2}$ of carotenoids (24.60-40.29 day) by HPH treatment was higher than the value of 19.21 day by heat treatment. This signified the negative effect of heat treatment on carotenoid retention during storage (Liu et al., 2019c). Overall, carotenoids remain quite stable during $\mathrm{HPH}$ treatment.

\section{CONCLUSIONS}

$\mathrm{HPH}$ is a promising technology that could open up new opportunities to preserve phytochemicals of liquid food products. Studies on using $\mathrm{HPH}$ have shown relative improvement in recovery of carotenoids and phenolic compounds from plant matrix. The impact of $\mathrm{HPH}$ treatment on the stability of phytochemicals is depended on the type of phytochemical. Generally, the stability of carotenoids in various food matrices upon $\mathrm{HPH}$ treatment is maintained. The stability of polyphenols upon $\mathrm{HPH}$ treatment is dependent on the HPH pressure that was applied and number of $\mathrm{HPH}$ passes. Conversely, the stability of vitamin $\mathrm{C}$ is affected by $\mathrm{HPH}$ treatment. The HPH pressure applied, number of $\mathrm{HPH}$ cycles or passes and inlet temperature of a $\mathrm{HPH}$ system are key factors that will have an impact on the extractability and stability of phytochemicals. In addition, the HPH valve type or design and/or scale of $\mathrm{HPH}$ may also be the factors that can have an impact on the extractability and stability of phytochemicals. More studies to investigate these factors should be carried out. Nevertheless, HPH has a great potential to be used as treatment to improve the extractability and maintaining the stability of phytochemicals. $\mathrm{HPH}$ can also be used together with milder thermal processing. More research on the impact of $\mathrm{HPH}$ on the nutritional quality of food products should also be investigated in the future. 


\section{AUTHOR CONTRIBUTIONS}

SY: original draft preparation and writing. CS: review. WC: conceptualization, writing, review, and editing. All authors contributed to the article and approved the submitted version.

\section{REFERENCES}

Amador-Espejo, G. G., Gallardo-Chacon, J. J., Nykanen, H., Juan, B., and Trujillo, A. J. (2015). Effect of ultra high-pressure homogenization on hydro- and liposoluble milk vitamins. Food Res. Int. 77, 49-54. doi: 10.1016/j.foodres.2015.04.025

Augusto, P. E. D., Tribst, A. A. L., and Cristianini, M. (2018). "High hydrostatic pressure and high-pressure homogenization processing of fruit juices," in Fruit Juices, eds G. Rajauria and B. K. Tiwari (San Diego, CA: Academic Press), 393-421.

Azmir, J., Zaidul, I. S. M., Rahman, M. M., Sharif, K. M., Mohamed, A., and Sahena, F. (2013). Techniques for extraction of bioactive compounds from plant materials: a review. J. Food Eng. 117, 426-436. doi: 10.1016/j.jfoodeng.2013.01.014

Ball, G. F. M. (2006). "Vitamin C", in Vitamins in Foods Analysis, Bioavailability, and Stability, ed G. F. M. Ball (Boca Raton, FL: Taylor \& Francis), 289-305.

Boon, C. S., McClements, D. J., Weiss, J., and Decker, E. A. (2010). Factors influencing the chemical stability of carotenoids in foods. Crit. Rev. Food Sci. Nutr. 50, 515-532. doi: 10.1080/10408390802565889

Bot, F., Calligaris, S., Cortella, G., Plazzotta, S., Nocera, F., and Anese, M. (2018). Study on high pressure homogenization and high power ultrasound effectiveness in inhibiting polyphenoloxidase activity in apple juice. J. Food Eng. 221, 70-76. doi: 10.1016/j.jfoodeng.2017.10.009

Brennan, C. S., Brunton, N., and Tiwari, B. K. (2013). Handbook of Plant Food Phytochemicals Sources, Stability and Extraction. Chichester: Wiley-Blackwell.

Briviba, K., Graf, V., Walz, E., Guamis, B., and Butz, P. (2016). Ultra high pressure homogenization of almond milk: physico-chemical and physiological effects. Food Chem. 192, 82-89. doi: 10.1016/j.foodchem.2015.06.063

Buckow, R., Weiss, U., and Knorr, D. (2009). Inactivation kinetics of apple polyphenol oxidase in different pressure-temperature domains. Innov. Food Sci. Emerg. Technol. 10, 441-448. doi: 10.1016/j.ifset.2009.05.005

Calligaris, S., Foschia, M., Bartolomeoli, I., Maifreni, M., and Manzocco, L. (2012). Study on the applicability of high-pressure homogenization for the production of banana juices. LWT Food Sci. Technol. 45, 117-121. doi: 10.1016/j.lwt.2011.07.026

Cardoso, L., Serrano, C., Quintero, E., López, C., Antezana, R., de la Ossa, E. J., et al. (2013). High pressure extraction of antioxidants from Solanum stenotomun peel. Molecules 18, 3137-3151. doi: 10.3390/molecules 18033137

Carlton, J. S. (2012). "Cavitation", in Marine Propellers and Propulsion, ed J. S. Carlton (Amsterdam: Elsevier), 209-233.

Carreño, J. M., Gurrea, M. C., Sampedro, F., and Carbonell, J. V. (2011). Effect of high hydrostatic pressure and high-pressure homogenisation on Lactobacillus plantarum inactivation kinetics and quality parameters of mandarin juice. Eur. Food Res. Technol. 232, 265-274. doi: 10.1007/s00217-0101381-9

Casquete, R., Castro, S. M., Villalobos, M. C., Serradilla, M., Queirós, R., Saraiva, J., et al. (2014). High pressure extraction of phenolic compounds from citrus peels. High Pres. Res. 34, 447-451. doi: 10.1080/08957959.2014.98 6474

Chaudhary, P., Sharma, A., Singh, B., and Nagpal, A. (2018). Bioactivities of phytochemicals present in tomato. J. Food Sci. Technol. 55, 2833-2849. doi: $10.1007 / \mathrm{s} 13197-018-3221-\mathrm{z}$

Cheynier, V. (2012). Phenolic compounds: from plants to foods. Phytochem. Rev. 11, 153-177. doi: 10.1007/s11101-012-9242-8

Choo, W. S. (2019). "Fruit pigment changes during ripening", in Encyclopedia of Food Chemistry, eds P. Varelis, L. Melton, and F. Shahidi (Amsterdam: Elsevier), 117-123.

\section{FUNDING}

WC gratefully acknowledged the support provided by Monash University Malaysia for her to visit the Center for Nonthermal Processing of Food, Washington State University, Pullman, U.S.A. as part of her Outside Study Program.

Colle, I., Lemmens, L., van Buggenhout,. S., an Loey, A., and Hendrickx, M (2010b). Effect of thermal processing on the degradation, isomerization, and bioaccessibility of lycopene in tomato pulp. J. Food Sci. 75, C753-C759. doi: 10.1111/j.1750-3841.2010.01862.x

Colle, I., van Buggenhout, S., van Loey, A., and Hendrickx, M. (2010a). High pressure homogenization followed by thermal processing of tomato pulp: influence on microstructure and lycopene in vitro bioaccessibility. Food Res. Int. 43, 2193-2200. doi: 10.1016/j.foodres.2010.07.029

Dhanani, T., Shah, S., Gajbhiye, N. A., and Kumar, S. (2017). Effect of extraction methods on yield, phytochemical constituents and antioxidant activity of Withania somnifera. Arab J. Chem. 10, S1193-S1199. doi: 10.1016/j.arabjc.2013.02.015

Diels, A. M. J., and Michiels, C. W. (2006). High-pressure homogenization as a non-thermal technique for the inactivation of microorganisms. Crit. Rev. Microbiol. 32, 201-216. doi: 10.1080/10408410601023516

Dumay, E., Chevalier-Lucia, D., Picart-Palmade, L., Benzaria, A., Gràcia-Julià, A., and Blayo, C. (2013). Technological aspects and potential applications of (ultra) high-pressure homogenisation. Trends Food Sci. Technol. 31, 13-26. doi: 10.1016/j.tifs.2012.03.005

Frank, K., Köhler, K., and Schuchmann, H. P. (2012). Stability of anthocyanins in high pressure homogenisation. Food Chem. 130, 716-719. doi: 10.1016/j.foodchem.2011.07.086

Georget, E., Miller, B., Callanan, M., Heinz, V., and Mathys, A. (2014). (Ultra) High pressure homogenization for continuous high pressure sterilization of pumpable foods - a review. Front. Nutr. 1:15. doi: 10.3389/fnut.2014.00015

Harjo, B., Wibowo, C., and Ng, K. M. (2004). Development of natural product manufacturing processes: phytochemicals. Chem. Eng. Res. Des. 82, 1010-1028. doi: 10.1205/0263876041580695

Haroen, U., Marlida, Y., Mirzah, and Budianyah, A. (2013). Extraction and isolation phytochemical and antimicrobial activity of limonoid compounds from orange waste juice. Pak. J. Nutr. 12, 730-735. doi: $10.3923 /$ pjn.2013.730.735

Harte, F. (2016). "Food processing by high-pressure homogenization", in High Pressure Processing of Food: Principles, Technology and Applications, eds V. M. Balasubramaniam, G. V. Barbosa- Canovas, and H. L. M. Lelieveld (New York, NY: Springer), 123-141.

Hayes, M. G., Fox, P. F., and Kelly, A. L. (2005). Potential applications of high pressure homogenisation in processing of liquid milk. J. Dairy Res. 72, 25-33. doi: 10.1017/S0022029904000524

He, Z. Y., Tao, Y. D., Zeng, M. M., Zhang, S., Tao, G. J., Qin, F., et al. (2016). High pressure homogenization processing, thermal treatment and milk matrix affect in vitro bioaccessibility of phenolics in apple, grape and orange juice to different extents. Food Chem. 200, 107-116. doi: 10.1016/j.foodchem.2016.01.045

Jurić, S., Ferrari, G., Velikov, K. P., and Donsì, F. (2019). High-pressure homogenization treatment to recover bioactive compounds from tomato peels. J. Food Eng. 262, 170-180. doi: 10.1016/j.jfoodeng.2019.06.011

Karaaslan, M., Yilmaz, F. M., Cesur, Ö., Vardin, H., Ikinci, A., and Dalgiç, A. C. (2013). Drying kinetics and thermal degradation of phenolic compounds and anthocyanins in pomegranate arils dried under vacuum conditions. Int. J. Food Sci. Technol. 49, 595-605. doi: 10.1111/ijfs.12342

Karacam, C. H., Sahin, S., and Oztop, M. H. (2015). Effect of high pressure homogenization (microfluidization) on the quality of Ottoman Strawberry (F-Ananassa) juice. LWT Food Sci. Technol. 64, 932-937. doi: 10.1016/j.lwt.2015.06.064

Khoo, H.-E., Prasad, K., Kong, K.-W., Jiang, Y., and Ismail, A. (2011). Carotenoids and their isomers: color pigments in fruits and vegetables. Molecules 16, 1710-1738. doi: 10.3390/molecules 16021710 
Knockaert, G., Lemmens, L., Van Buggenhout, S., Hendrickx, M., and Loey, A. V. (2012a). Changes in $\beta$-carotene bioaccessibility and concentration during processing of carrot puree. Food Chem. 133, 60-67. doi: 10.1016/j.foodchem.2011.12.066

Knockaert, G., Pulissery, S. K., Colle, I., van Buggenhout, S., Hendrickx, M., and Loey, A. V. (2012b). Lycopene degradation, isomerization and in vitro bioaccessibility in high pressure homogenized tomato puree containing oil: effect of additional thermal and high pressure processing. Food Chem. 135, 1290-1297. doi: 10.1016/j.foodchem.2012.05.065

Kubo, M. T. K., Augusto, P. E. D., and Cristianini, M. (2013). Effect of high pressure homogenization $(\mathrm{HPH})$ on the physical stability of tomato juice: creep and recovery behaviours. Food Res. Int. 51, 170-179. doi: 10.1016/j.foodres.2013.06.027

Lemmens, L., Tchuenche, E. S., van Loey, A. M., and Hendrickx, M. E. (2013). Betacarotene isomerisation in mango puree as influenced by thermal processing and high-pressure homogenisation. Eur. Food Res. Technol. 236, 155-163. doi: 10.1007/s00217-012-1872-y

Levy, R., Okun, Z., and Shpigelman, A. (2020). High-pressure homogenization: principles and applications beyond microbial inactivation. Food Eng. Rev. doi: 10.1007/s12393-020-09239-8. [Epub ahead of print].

Liu, J., Bi, J., Liu, X., Zhang, B., Wu, X., Wellala, C. K. D., et al. (2019c). Effects of high 552 pressure homogenization and addition of oil on the carotenoid bioaccessibility of carrot juice. Food Funct. 10, 458-468. doi: 10.1039/C8FO01925H

Liu, W., Liu, J., Xie, M., Liu, C., Liu, W., and Wan, J. (2009). Characterization and high-pressure microfluidization-induced activation of polyphenoloxidase from chinese pear (Pyrus pyrifolia Nakai). J. Agric. Food Chem. 57, 5376-5380. doi: 10.1021/jf9006642

Liu, X., Liu, J., Bi, J., Cao, F., Ding, Y., and Peng, J. (2019a). Effects of high pressure homogenization on physical stability and carotenoid degradation kinetics of carrot beverage during storage. J. Food Eng. 263, 63-69. doi: 10.1016/j.jfoodeng.2019.05.034

Liu, X., Liu, J., Bi, J., Yi, J., Peng, J., Ning, C., et al. (2019b). Effects of high pressure homogenization on pectin structural characteristics and carotenoid bioaccessibility of carrot juice. Carbohydr. Polym. 203, 176-184. doi: 10.1016/j.carbpol.2018.09.055

Maresca, P., Donsì, F., and Ferrari, G. (2011). Application of a multi-pass highpressure homogenization treatment for the pasteurization of fruit juices. J. Food Eng. 104, 364-372. doi: 10.1016/j.jfoodeng.2010.12.030

Marszałek, K., Wozniak, Ł., Kruszewski, B., and Skapska, S. (2017). The effect of high pressure techniques on the stability of anthocyanins in fruit and vegetables. Int. J. Mol. Sci. 18:277. doi: 10.3390/ijms18020277

Martinez-Monteagudo, S., Yan, B., and Balasubramaniam, V. M. (2017). Engineering process characterization of high-pressure homogenization - from laboratory to industrial scale. J. Food Eng. 117, 426-436. doi: 10.1007/s12393-016-9151-5

Martínez-Valverde, I., Periago, M. J., Provan, G., and Chesson, A. (2002). Phenolic compounds, lycopene and antioxidant activity in commercial varieties of tomato (Lycopersicum esculentum). J. Sci. Food Agric. 82, 323-330. doi: $10.1002 /$ jsfa. 1035

Mattila, P., and Kumpulainen, J. (2002). Determination of free and total phenolic acids in plant-derived foods by HPLC with diode-array detection. J. Agric. Food Chem. 50, 3660-3667. doi: 10.1021/jf020028p

Mckay, A. M., Linton, M., Stirling, J., Mackle, A., and Patterson, M. F. (2011). A comparative study of changes in the microbiota of apple juice treated by high hydrostatic pressure (HHP) or high pressure homogenisation (HPH). Food Microbiol. 28, 1426-1431. doi: 10.1016/j.fm.2011.06.013

Mesa, J., Hinestroza-Cordoba, L. I., Barrera, C., Segu, L., Betoret, E., and Betoret, N. (2020). High homogenization pressures to improve food quality, functionality and sustainability. Molecules 25:19. doi: 10.3390/molecules25143305

Moscovici Joubran, A., Katz, I. H., Okun, Z., Davidovich-Pinhas, M., and Shpigelman, A. (2019). The effect of pressure level and cycling in high-pressure homogenization on physicochemical, structural and functional properties of filtered and non-filtered strawberry nectar. Innov. Food Sci. Emerg. Technol. 57:102203. doi: 10.1016/j.ifset.2019.102203

Oancea, A.-M., Onofrei, C., Turturiča, M., Bahrim, G., Râpeanu, G., and Stănciuc, N. (2018). The kinetics of thermal degradation of polyphenolic compounds from elderberry (Sambucus nigra L.) extract. Food Sci. Technol. Int. 24, 361-369. doi: $10.1177 / 1082013218756139$

Palmero, P., Colle, I., Lemmens, L., Panozzo, A., Nguyen, T. T. M., Hendrickx, M., et al. (2016a). Enzymatic cell wall degradation of high-pressure-homogenized tomato puree and its effect on lycopene bioaccessibility. J. Sci. Food Agric. 96, 254-261. doi: 10.1002/jsfa.7088

Palmero, P., Panozzo, A., Colle, I., Chigwedere, C., Hendrickx, M., and van Loey, A. (2016b). Role of structural barriers for carotenoid bioaccessibility upon high pressure homogenization. Food Chem. 199, 423-432. doi: 10.1016/j.foodchem.2015.12.062

Panozzo, A., Lemmens, L., van Loey, A., Manzocco, L., Nicoli, M. C., and Hendrickx, M. (2013). Microstructure and bioaccessibility of different carotenoid species as affected by high pressure homogenisation: a case study on differently coloured tomatoes. Food Chem. 141, 4094-4100. doi: 10.1016/j.foodchem.2013.06.099

Patras, A., Brunton, N. P., O’Donnell, C., and Tiwari, B. K. (2010). Effect of thermal processing on anthocyanin stability in foods: mechanisms and kinetics of degradation. Trends Food Sci. Technol. 21, 3-11. doi: 10.1016/j.tifs.2009.07.004

Patrignani, F., Mannozzi, C., Tappi, S., Tylewicz, U., Pasini, F., Castellone, V., et al. (2019). (Ultra) high pressure homogenization potential on the shelf-life and functionality of kiwifruit juice. Front. Microbiol. 10:246. doi: 10.3389/fmicb.2019.00246

Pérez-Conesa, D., García-Alonso, J., García-Valverde, V., Iniesta, M.-D., Jacob, K., Sánchez-Siles, L. M., et al. (2009). Changes in bioactive compounds and antioxidant activity during homogenization and thermal processing of tomato puree. Innov. Food Sci. Emerg. Technol. 10, 179-188. doi: 10.1016/j.ifset.2008.12.001

Plazzotta, S., and Manzocco, L. (2019). High-pressure homogenisation combined with blanching to turn lettuce waste into a physically stable juice. Innov. Food Sci. Emerg. Technol. 52, 136-144. doi: 10.1016/j.ifset.2018.11.008

Puri, M., Sharma, D., and Barrow, C. J. (2012). Enzyme-assisted extraction of bioactives from plants. Trends Biotechnol. 30, 37-44. doi: 10.1016/j.tibtech.2011.06.014

Quan, W., Tao, Y., Qie, X., Zeng, M., Qin, F., Chen, J., et al. (2020). Effects of highpressure homogenization, thermal processing, and milk matrix on the in vitro bioaccessibility of phenolic compounds in pomelo and kiwi juices. J. Funct. Foods 64:103633. doi: 10.1016/j.jff.2019.103633

Rizk, E. M., El-Kady, A. T., and El-Bialy, A. R. (2014). Charactrization of carotenoids (lyco-red) extracted from tomato peels and its uses as natural colorants and antioxidants of ice cream. Ann. Agric. Sci. 59, 53-61. doi: 10.1016/j.aoas.2014.06.008

Rosa, R. M. S. (2006). "Turbulence theories”, in Encyclopedia of Mathematical Physics, eds J-P. Françoise, G. L. Naber, and T. S. Tsun (Oxford: Academic Press), 295-303.

Saldo, J., Suárez-Jacobo, Á., Gervilla, R., Guamis, B., and Roig-Sagués, A. X. (2009). Use of ultra-high-pressure homogenization to preserve apple juice without heat damage. High Pres. Res. 29, 52-56. doi: 10.1080/08957950802715112

Samarin, A. M., Poorazarang, H., Hematyar, N., and Elhamirad, A. (2012). Phenolics in potato peels: extraction and utilization as natural antioxidants. World Appl. Sci. J. 18, 191-195. doi: 10.5829/idosi.wasj.2012.18.02.1057

Sanguansri, P., and Augustin, M. A. (2006). Nanoscale materials development - a food industry perspective. Trends Food Sci. Technol. 17, 547-556. doi: 10.1016/j.tifs.2006.04.010

Saricaoglu, F. T., Atalar, I., Yilmaz, V. A., Odabas, H. I., and Gul, O. (2019). Application of multi pass high pressure homogenization to improve stability, physical and bioactive properties of rosehip (Rosa canina L.) nectar. Food Chem. 282, 67-75. doi: 10.1016/j.foodchem.2019. 01.002

Schilling, S., Schmid, S., Jäger, H., Ludwig, M., Dietrich, H., Toepfl, S., et al. (2008). Comparative study of pulsed electric field and thermal processing of apple juice with particular consideration of juice quality and enzyme deactivation. J Agric. Food Chem. 56, 4545-4554. doi: 10.1021/jf073 2713

Schweiggert, R. M., Mezger, D., Schimpf, F., Steingass, C. B., and Carle, R. (2012). Influence of chromoplast morphology on carotenoid bioaccessibility of carrot, mango, papaya, and tomato. Food Chem. 135, 2736-2742. doi: 10.1016/j.foodchem.2012.07.035 
Selvamuthukumaran, M., and Shi, J. (2017). Recent advances in extraction of antioxidants from plant by-products processing industries. Food Qual. Saf. 1, 61-81. doi: 10.1093/fqsafe/fyx004

Serment-Moreno, V., Jacobo-Velázquez, D. A., Torres, J. A., and Welti-Chanes, J. (2017). Microstructural and physiological changes in plant cell induced by pressure: their role on the availability and pressure-temperature stability of phytochemicals. Food Eng. Rev. 9, 314-334. doi: 10.1007/s12393-017-9158-6

Sharabi, S., Okun, Z., and Shpigelman, A. (2018). Changes in the shelf life stability of riboflavin, vitamin $\mathrm{C}$ and antioxidant properties of milk after (ultra) high pressure homogenization: direct and indirect effects. Innov. Food Sci. Emerg. Technol. 47, 161-169. doi: 10.1016/j.ifset.2018.02.014

Shi, J., Maguer, M. L., Kakuda, Y., Liptay, A., and Niekamp, F. (1999). Lycopene degradation and isomerization in tomato dehydration. Food Res. Int. 32, 15-21. doi: 10.1016/S0963-9969(99)00059-9

Suárez-Jacobo, Á., Rüfer, C. E., Gervilla, R., Guamis, B., Roig-Sagués, A. X., and Saldo, J. (2011). Influence of ultra-high pressure homogenisation on antioxidant capacity, polyphenol and vitamin content of clear apple juice. Food Chem. 127, 447-454. doi: 10.1016/j.foodchem.2010.12.152

Toro-Funes, N., Bosch-Fuste, J., Veciana-Nogues, M. T., and VidalCarou, M. C. (2014a). Effect of ultra high pressure homogenization treatment on the bioactive compounds of soya milk. Food Chem. 152, 597-602. doi: 10.1016/j.foodchem.2013.12.015

Toro-Funes, N., Bosch-Fuste, J., Veciana-Nogues, M. T., and Vidal-Carou, M. C. (2014b). Influence of ultra-high-pressure homogenization treatment on the phytosterols, tocopherols, and polyamines of almond beverage. J. Agric. Food Chem. 62, 9539-9543. doi: 10.1021/jf503324f

Tribst, A. A. L., Franchi, M. A., de Massaguer, P. R., and Cristianini, M. (2011). Quality of mango nectar processed by high-pressure homogenization with optimized heat treatment. J. Food Sci. 76, M106-M110. doi: 10.1111/j.1750-3841.2010.02006.x

Velázquez-Estrada, R. M., Hernández-Herrero, M. M., Rüfer, C. E., GuamisLópez, B., and Roig-Sagués, A. X. (2013). Influence of ultra high pressure homogenization processing on bioactive compounds and antioxidant activity of orange juice. Innov. Food Sci. Emerg. Technol. 18, 89-94. doi: 10.1016/j.ifset.2013.02.005

Volf, I., Ignat, I., Neamtu, M., and Popa, V. I. (2014). Thermal stability, antioxidant activity, and photo-oxidation of natural polyphenols. Chem. Pap. 68, 121-129. doi: 10.2478/s11696-013-0417-6

Wang, L., and Weller, C. L. (2006). Recent advances in extraction of nutraceuticals from plants. Trends Food Sci. Technol. 17, 300-312. doi: 10.1016/j.tifs.2005.12.004

Wellala, C. K. D., Bi, J., Liu, X., Liu, J., Lyu, J., Zhou, M., et al. (2020). Effect of high pressure homogenization combined with juice ratio on water-soluble pectin characteristics, functional properties and bioactive compounds in mixed juices. Innov. Food Sci. Emerg. Technol. 60:102279. doi: 10.1016/j.ifset.2019.102279

Welti-Chanes, J., Ochoa-Velasco, C. E., and Guerrero-Beltrán, J. Á. (2009). Highpressure homogenization of range juice to inactivate pectinmethylesterase. Innov. Food Sci. Emerg. Technol. 10, 457-462. doi: 10.1016/j.ifset.2009. 05.012

Yan, B., Martínez-Monteagudo, S. I., Cooperstone, J. L., Riedl, K. M., Schwartz, S. J., and Balasubramaniam, V. M. (2017). Impact of thermal and pressure-based technologies on carotenoid retention and quality attributes in tomato juice. Food Bioproc. Technol. 10, 808-818. doi: 10.1007/s11947-016-1859-y

Yang, J. X., Jin, X., and Chen, X. D. (2018). Investigation of the effects of mechanical treatments on cellular structure integrity and vitamin $\mathrm{C}$ extractability of broccoli (Brassica oleracea L. var. italica) by LF-NMR. Food Funct. 9, 2942-2950. doi: 10.1039/c8fo00140e

Yildiz, G. (2019). Application of ultrasound and high-pressure homogenization against high temperature-short time in peach juice. J. Food Process Eng. 42:e12997. doi: 10.1111/jfpe.12997

Yu, Y., Xu, Y., Wu, J., Xiao, G., Fu, M., and Zhang, Y. (2014). Effect of ultrahigh pressure homogenisation processing on phenolic compounds, antioxidant capacity and anti-glucosidase of mulberry juice. Food Chem. 153, 14-120. doi: 10.1016/j.foodchem.2013.12.038

Zeng, Y., Du, J., Wang, L., Pan, Z., Xu, Q., Xiao, S., et al. (2015). A comprehensive analysis of chromoplast differentiation reveals complex protein changes associated with plastoglobule biogenesis and remodeling of protein systems in sweet orange flesh. Plant Physiol. 168, 1648-1665. doi: 10.1104/pp.15.00645

Zhou, L., Guan, Y., Bi, J., Liu, X., Yi, J., Chen, Q., et al. (2017). Change of the rheological properties of mango juice by high pressure homogenization. $L W T$ Food Sci. Technol. 82, 121-130. doi: 10.1016/j.lwt.2017.04.038

Zhu, X., Cheng, Y., Chen, P., Peng, P., Liu, S., Li, D., et al. (2016). Effect of alkaline and high-pressure homogenization on the extraction of phenolic acids from potato peels. Innov. Food Sci. Emerg. Technol. 37, 91-97. doi: $10.1016 /$ j.ifset.2016.08.006

Conflict of Interest: The authors declare that the research was conducted in the absence of any commercial or financial relationships that could be construed as a potential conflict of interest.

Copyright (C) 2021 Yong, Song and Choo. This is an open-access article distributed under the terms of the Creative Commons Attribution License (CC BY). The use, distribution or reproduction in other forums is permitted, provided the original author(s) and the copyright owner(s) are credited and that the original publication in this journal is cited, in accordance with accepted academic practice. No use, distribution or reproduction is permitted which does not comply with these terms. 